\title{
Omalizumab retreatment in patients with chronic spontaneous urticaria: a systematic review of published evidence
}

\author{
${ }^{1}$ Institute of Clinical Physiology-National Research Council of Italy (IFC-CNR), Pisa, Italy \\ ${ }^{2}$ Department of Emergency and Organ Transplantation, School and Chair of Allergology and Clinical Immunology, Uni- \\ versity of Bari Aldo Moro, Bari, Italy. \\ ${ }^{3}$ Allergology Clinic, Clinica San Carlo, Paderno Dugnano, Milan, Italy \\ ${ }^{4}$ ImmunoAllergology Unit, Careggi University Hospital of Florence, Florence, Italy \\ ${ }^{5}$ Allergy Unit, Azienda Ospedaliero-Universitaria Ospedali Riuniti, Ancona, Italy \\ ${ }^{6}$ School and Unit of Allergy and Clinical Immunology, Department of Clinical and Experimental Medicine, University of \\ Messina, Messina, Italy
}

\section{KEY WORDS \\ chronic urticaria; omalizumab; retreatment; therapy}

\section{Corresponding author}

Riccardo Asero

Allergology Clinic

Clinica San Carlo

Via Ospedale 21

20037 Paderno Dugnano, Milan, Italy

E-mail: r.asero@libero.it

\section{Doi}

10.23822/EurAnnACI.1764-1489.136

\begin{abstract}
Summary
A systematic review of the current literature on retreatment with omalizumab of patients with relapsing chronic spontaneous urticaria was performed. Published evidence shows that retreatment is safe and clinically effective, and that time to complete clinical response reduces as the number of retreatments increases.
\end{abstract}

\section{Introduction}

Chronic urticaria (CU) is a dermatological disease characterized by the rapid appearance of itchy hives, angioedema or both, lasting for 6 weeks or more (1). Approximately $0.5-1 \%$ of the general population suffers from $\mathrm{CU}$ and over $60 \%$ of cases are classified as chronic spontaneous (previously termed idiopathic) urticaria (CSU), for which no obvious triggers can be identified $(2,3)$. The average duration of CSU is generally up to 5 years, although more severe cases can last considerably longer $(2,4)$. The EAACI/GA2/LEN/EDF/WAO urticaria guidelines suggest using daily non-sedating (second generation) $\mathrm{H} 1$-antihistamines as first-line treatment (1). As second-line therapy, an increase up to four times the licensed antihistamine dose may be beneficial, but around $45 \%$ of patients fail to respond (5). For these cases, omalizumab is recommended as add-on therapy, as third-line treatment option.

Omalizumab is a humanized monoclonal antibody recognizing the $\mathrm{Fc}$ portion of the immunoglobulin $\mathrm{E}$ ( $\mathrm{IgE}$ ) molecule. It is thought to reduce IgE- and FceRI-mediated mast cell and basophil activation $(6,7)$, with a similar outcome on both mast cells and basophils. Launched around 20 years ago to treat patients with severe asthma non responsive to standard treatment, it is currently used in several other allergic conditions including refractory CSU since 2013, displaying high efficacy and safety, especially when compared to first- and second-line therapies. 
Since then, a number of studies have been published, especially in real-life settings, aimed at finding the best strategy to administer omalizumab to optimize the treatment outcome. According to the review by Tonacci et al. (8), omalizumab 300 mg administered every 4 weeks appears to be the most effective and safe dose for the treatment of CSU, showing rapid response time. This approach displays minor adverse effects, and appears to be safe also when administered to pregnant women and their offspring. However, after the discontinuation of the drug, relapses may occur, with urticaria activity scores (UAS7) returning to pre-treatment levels in some cases, along with a poorer quality of life. In such cases, retreatment is advisable in order to increase patients' quality of life. Nevertheless, it is not clear which strategies in terms of dose and/or timing of omalizumab administration are the best to achieve good retreatment response. Within this framework, a literature review on studies about retreatment with omalizumab in CSU was carried out and results are presented and critically discussed in the present article.

\section{Materials and methods}

We performed a literature search in PubMed until January 2020 by using logical combinations of the following terms: "urticaria, chronic", "urticaria, idiopathic", "urticaria, chronic spontaneous", "omalizumab", "anti-IgE" and "retreatment". We included reports of original data, including double-blind placebo-controlled, randomized controlled trials (DBPC-RCT), RCTs, open controlled trials, observational studies, and retrospective trials. We excluded: (1) case reports, systematic reviews, review articles, meta-analyses, as well as papers not published in English language.

\section{Results}

According to the inclusion and exclusion criteria mentioned above, a handful of studies were retrieved. Overall literature search results are displayed in table I.

The works retrieved included a relatively low number of patients, mostly women, and were all concordant in stating that the first subcutaneous dose of omalizumab should be $300 \mathrm{mg}$ administered every 4 weeks, with the exception of Metz et al. (9), where the initial dose and administration interval differed according to the dose and interval used to obtain a remission during the first treatment course.

Where information on dosage was available, retreatment was carried out with the same dose of omalizumab administered during the previous round. Overall, retreatment with omalizumab was safe and effective in nearly all cases, with minor side effects reported, including mild, transient local immediate skin reactions (15). Furthermore, the time to achieve complete remission decreased with subsequent treatment cycles. As observed by Nettis et al. (11), patients showed an average complete remission after 4.9 weeks during the first treatment course, dropping to 3.8 and 1.8 on the second and third retreatment courses, respectively, hence demonstrating an increased rapidity of response to treatment after multiple cycles.

Another important strategy to consider is how to choose the best timing for retreatment. From our review it is difficult to draw definite conclusions, since all the studies adopted different timing protocols and all of them obtained satisfying results. However, both the studies by Metz et al. (9), where the timing was adapted according to the occurrence of relapses, and Nettis et al. (11), where omalizumab was administered at least 8 weeks after the end of the previous course, achieved optimal results.

\section{Conclusions}

The present review confirms the optimal efficacy and safety of omalizumab to treat refractory CSU in most cases. Overall, retreatment seems to provide the best results in terms of efficacy using the same dose as in the first cycle, usually $300 \mathrm{mg}$ injected subcutaneously every 4 weeks. In any case, the interval between two subsequent treatment courses should be controlled and not exceed 8 weeks, to avoid delayed efficacy.

Future studies should address retreatment efficacy on larger samples, also trying to reduce the current gender bias by including more male subjects with CSU treated with omalizumab. 
Table I - Studies retrieved in the literature search.

\begin{tabular}{|c|c|c|c|c|}
\hline Study & No. of patients & Treatment & Retreatment & Results \\
\hline $\begin{array}{l}\text { Metz et al., } \\
2014 \text { (9) }\end{array}$ & $\begin{array}{l}25 \text { patients with } \\
\text { CSU and/or } \\
\text { CIndU (aged } \\
18-74 \text { years; } 18 \\
\text { women) }\end{array}$ & $\begin{array}{l}150 \text { to } 600 \\
\mathrm{mg} / \mathrm{month} \\
\text { subcutaneously } \\
\text { in 2- to 4-week } \\
\text { intervals }\end{array}$ & $\begin{array}{l}\text { Retreatment initiated after } \\
\text { the recurrence of symptoms. } \\
\text { All patients received the } \\
\text { same dose of omalizumab in } \\
\text { the same interval as the last } \\
\text { successful treatment before } \\
\text { discontinuation }\end{array}$ & $\begin{array}{l}\text { Rapid and complete response after the first injection } \\
\text { within the first } 4 \text { weeks of retreatment for all patients }\end{array}$ \\
\hline $\begin{array}{l}\text { Nettis et al., } \\
2018 \text { (11) }\end{array}$ & $\begin{array}{l}31 \text { patients } \\
\text { with refractory } \\
\text { CSU (mean age: } \\
48.1 \pm 13.4 ; 22 \\
\text { women) }\end{array}$ & $\begin{array}{l}300 \text { mg every } \\
4 \text { weeks for } \\
24 \text { weeks } \\
\text { subcutaneously } \\
\text { (first treatment } \\
\text { course) }\end{array}$ & $\begin{array}{l}\text { Retreatment (second and } \\
\text { third treatment course) at } \\
\text { least } 8 \text { weeks after the end of } \\
\text { the previous course }\end{array}$ & $\begin{array}{l}\text { First course: complete response for all patients, relapse } \\
\text { within } 5-20 \text { weeks. } \\
\text { Second course: complete response in } 93.5 \% \text { of patients. } \\
\text { Symptoms remission within } 5 \text { - } 16 \text { weeks after their last } \\
\text { injection. } \\
\text { Third course: complete remission in } 93.8 \% . \geq 8 \text { weeks } \\
\text { after the administration of the last dose, } 68.7 \% \text { had } \\
\text { relapse of CSU. Complete therapeutic response in } 4.9 \\
\text { weeks (first course), } 3.8 \text { weeks (second course), } 1.8 \text { weeks } \\
\text { (third course) }\end{array}$ \\
\hline
\end{tabular}

\begin{tabular}{llll}
\hline Nettis et al., & 24 patients & $300 \mathrm{mg}$ every & $300 \mathrm{mg}$ every 4 weeks for 24 \\
$2018(12)$ & with refractory & $\begin{array}{l}4 \text { weeks for } \\
\text { weeks (second course) after }\end{array}$ \\
& $\begin{array}{l}\text { CSU (mean age: } \\
48.0 \pm 13.7 ; 14\end{array}$ & $\begin{array}{l}\text { 24 weeks (first } \\
\text { treatment }\end{array}$ & $\begin{array}{l}\text { 8-16-week follow-up } \\
\text { course) }\end{array}$ \\
&
\end{tabular}

First course: good efficacy; relapse within 9-19 weeks. Similar efficacy during re-treatment, with slightly lower efficacy compared to the first course

Türk et al., 25 patients with $300 \mathrm{mg} / 4$ weeks In all patients with 2018 (13) CSU (age: 31- for at least $3 \quad$ complete or partial 49; 18 women) months response: discontinuation of omalizumab after 6 months; $58 \%$ had complete response at the end of treatment. At the 3rd month, 32\% had complete response. Eleven patients experienced relapse, omalizumab was restarted in 10 of them. After the re-initiation retreatment at the same initial of omalizumab, 5 had complete response and 5 had dose if the recurred disease couldn't be controlled with concomitant medications partial response. Seven patients achieved remission after discontinuation. Time from the last omalizumab dose was 8 weeks / 18 months

\begin{tabular}{lll}
\hline Matucci et & 30 patients with & $300 \mathrm{mg} / 4$-week \\
al., 2019 & CSU (age: $20-$ & intervals for 6 \\
(14) & $70 ; 22$ women) & administrations
\end{tabular}

\section{Retreatment with the} same protocol in relapsing patients; in case of a second relapse, a third treatment was performed
Cycle 1: after 6 months, $83.4 \%$ were responders, $13.3 \%$ partial responders, $3.3 \%$ did not respond. Time to achieve a partial or complete response: $5.8 \pm 1$ weeks. $79.1 \%$ relapsed within $12.5 \pm 4.0$ weeks.

Cycle 2: $14 / 15$ improved their symptoms $(57.1 \%$ complete remission). Mean response time: $5.0 \pm 1.3$ vs $6.1 \pm 1.4$ weeks (first cycle). $53.8 \%$ relapsed. Cycle 3: 7/7 had complete remission

$\begin{array}{lll}\text { Vollono et } & 32 \text { patients with } & \text { Subcutaneous } \\ \text { al., 2019 } & \text { CSU (age: } 27- & 300 \mathrm{mg} / 4 \\ (15) & 72 ; 22 \text { women) } & \text { weeks as add- } \\ & & \text { on to H1- } \\ & & \text { antihistamines } \\ & \text { for } 6 \text { months }\end{array}$

$300 \mathrm{mg}$ every 4 weeks for 513 patients completed 2 cycles of treatment, 10 patients months in case of recurrence had completed 1 cycle of treatment, 8 patients had in an 8 -week treatment undergone $1 / 2$ cycle of treatment. interruption

Mild, transient local skin immediate reactions observed in one patient.

20 patients added second-generation $\mathrm{H} 1$-antihistamines due to persistence of pruritus and wheals after 2-4 weeks of treatment with omalizumab monotherapy. 


\section{Conflict of interests}

The authors declare that they have no conflict of interests.

\section{References}

1. Zuberbier T, Aberer W, Asero R, Abdul Latiff AH, Baker D, Ballmer-Weber B, et al. 1)The EAACI/GA²LEN/EDF/WAO guideline for the definition, classification, diagnosis and management of urticaria. Allergy 2018; 73(7):1393-1414.

2. Maurer M, Weller K, Bindslev-Jensen C, Giménez-Arnau A, Bousquet PJ, Bousquet J, et al. 1) Unmet clinical needs in chronic spontaneous urticaria. A GA2LEN task force report. Allergy 2011; 66(3):317-330.

3. Zuberbier T. Chronic urticaria. Curr Allergy Asthma Rep 2012; 12(4):267-272.

4. Beltrani VS. An overview of chronic urticaria. Clin Rev Allergy Immunol 2002; 23(2):147-169.

5. Staevska M, Popov TA, Kralimarkova T, Lazarova C, Kraeva S, Popova D, et al. J The effectiveness of levocetirizine and desloratadine in up to 4 times conventional doses in difficult-to-treat urticaria. Allergy Clin Immunol 2010; 125:676-682.

6. Saini SS, MacGlashan D. How IgE upregulates the allergic response. Curr Opin Immunol 2002; 14:694-697.

7. Beck LA, Marcotte GV, MacGlashan D, Togias A, Saini S. Omalizumab-induced reductions in mast cell FceRI expression and function. J Allergy Clin Immunol 2004; 114:527-530.

8. Tonacci A, Billeci L, Pioggia G, Navarra M, Gangemi S. Omalizumab for the Treatment of Chronic Idiopathic Urticaria: Systema- tic Review of the Literature. Pharmacotherapy 2017; 37(4):464480.

9. Metz M, Ohanyan T, Church MK, Maurer M. Retreatment with omalizumab results in rapid remission in chronic spontaneous and inducible urticaria. JAMA Dermatol 2014; 150: 288-290.

10. Mandel VD, Guanti MB, Liberati S, Demonte A, Pellacani G, Pepe P. Omalizumab in Chronic Spontaneous Urticaria Refractory to Conventional Therapy: An Italian Retrospective Clinical Analysis with Suggestions for Long-Term Maintenance Strategies. Dermatol Ther (Heidelb) 2018; 8(2):291-301.

11. Nettis E, Di Leo E, Foti C, Cegolon L, Vacca A. Efficacy and rapid activity of omalizumab retreatment in chronic spontaneous urticaria. J Am Acad Dermatol 2018; 78(6):1211-1213.

12. Nettis E, Cegolon L, Macchia L, Zaza I, Calogiuri G, Di Leo E. Efficacy of Omalizumab Treatment with Concomitant Antihistamines as Needed for Moderate, Refractory Chronic Spontaneous Urticaria. Acta Derm Venereol 2018; 98(4):446-448.

13. Türk M, Yılmaz İ, Bahçecioğlu SN. Treatment and retreatment with omalizumab in chronic spontaneous urticaria: Real life experience with twenty-five patients. Allergol Int 2018; 67:85-89.

14. Matucci A, Nencini F, Rossi O, Pratesi S, Parronchi P, Maggi E, Vultaggio A. The percentage of patients achieving complete remission of urticaria increases with repeated courses of treatment. J Allergy Clin Immunol Pract 2019; 7(1):339-340.

15. Vollono L, Piccolo A, Lanna C, Esposito M, Bavetta M, Campione E, Bianchi L, Diluvio L. Omalizumab for chronic spontaneous urticaria in "complex" patients: data from real-life clinical practice. Drug Des Devel Ther 2019; 13:3181-3186. 